\title{
Air Pollution Exposure as a Relevant Risk Factor for COPD Exacerbations in Male and Female Patients
}

\author{
Miguel Enrique Silva Rodriguez ${ }^{1}$, and Patricia Silveyra ${ }^{2, *}$ \\ 1 School of Public Health, Indiana University Bloomington Innovation Center. Bloomington, IN, 47408, USA \\ miguel.esilva@icloud.com \\ 2 School of Public Health, Indiana University Bloomington. 1025 E $7^{\text {th }}$ Street. Bloomington, IN 47405, USA; \\ psilveyr@iu.edu \\ * Correspondence: psilveyr@iu.edu
}

\begin{abstract}
Chronic obstructive pulmonary disease (COPD) is a multifactorial lung inflammatory disease affecting 174 million people worldwide, with a recently reported increased incidence in female patients. Patients with COPD are especially vulnerable to the detrimental effects of environmental exposures, especially from air particulate and gaseous pollutants. Exposure to air pollution severely influences COPD outcomes, resulting in acute exacerbations, hospitalizations, and death. In the current study, we conducted a review of the literature addressing air pollution induced acute exacerbations of COPD (AECOPD) in order to determine whether air pollution affects COPD patients in a sex-specific manner. We found that while the majority of studies enrolled both male and female patients, only a few reported results disaggregated by sex. Most studies had a higher enrollment of male patients, only four compared AECOPD outcomes between sexes, and only one study identified sex differences in AECOPD, with females displaying higher rates. Overall, our analysis of the literature confirmed that air pollution exposure is a trigger for AECOPD hospitalizations and revealed a significant gap in our knowledge of sex-specific effects of air pollutants on COPD outcomes, highlighting the need for more studies considering sex as a biological variable.
\end{abstract}

Keywords: COPD exacerbation; air pollution; hospital admission; sex differences

\section{Introduction}

\subsection{COPD Definition}

Chronic Obstructive Pulmonary Disease (COPD) is a lung inflammatory disease that includes emphysema and chronic bronchitis and is characterized by airflow blockage in the lungs [1]. The diagnosis of COPD includes spirometry values of less than $70 \%$ of predicted forced expiratory volume (FEV) that is incompletely reversible with the administration of an inhaled bronchodilator. Pathological features are observed in central airways, small airways, and alveolar spaces. The pathogenesis of COPD includes proteinaseantiproteinase imbalance, immunological mechanisms, oxidant-antioxidant balance, systemic inflammation, apoptosis, and ineffective repair, and accelerated decline in forced expiratory volume in 1 second (FEV1) and forced vital capacity (FVC) [1]. Airflow limitation in COPD is defined as a post-bronchodilator FEV1 to FVC ratio of 0.70 or lower. The diagnosis of COPD is also determined on the basis of symptoms and signs (e.g., exertional breathlessness, chronic cough, regular sputum production, frequent bronchitis, or wheeze, etc.) in people over 35 years of age who have a risk factor (e.g., smoking history), although these clinical findings have to be supported by spirometry, as defined by GOLD and NICE standards.

The development of COPD is multifactorial, and the risk factors include genetic, environmental, and sex and gender factors. While cigarette smoke is the most critical risk factor associated with COPD, occupational and other environmental exposures are known to cause approximately one in six cases [2]. Female sex and gender have also been 
independently associated with COPD development due to differential susceptibility to lung-damaging effects of cigarette smoking [3], interactions of female hormones with toxins present in tobacco products, and other factors such as exposure to household air pollution and environmental triggers $[4,5]$.

\subsection{Epidemiology}

COPD affects approximately 17.4 million people (7.3 million males vs. 10.1 million females) in the United States [6], and an estimated 174 million (104.3 million males and 69.7 million females) worldwide [7]. It is the fourth-leading cause of death and the fourth leading cause of chronic disease-related morbidity and mortality, accounting for more than 120,000 deaths annually in the United States and 3.2 million globally [7,8]. Several research studies have suggested that outdoor air pollution exposure is linked to the prevalence and incidence of COPD [9].

In the past few decades, the prevalence of COPD among women has significantly increased, from 50.8 to 58.2 per 1,000 people, while in men it has decreased from 108.1 to 74.3 per 1,000 people [10]. More recent data indicate that that the COPD prevalence was higher among women than men between 1998-2009 [2]. In addition, since the year 2000, the number of women dying from COPD has also surpassed the number of men [11,12]. These trends are partially explained by the higher susceptibility of women to the negative effects of smoking, which results in earlier development of severe forms of the disease, as well as historical differences in tobacco use, environmental and occupational exposures, and bias in disease diagnosis [13,14].

\subsection{Air quality as a risk factor}

Air pollution exposure is estimated to contribute to approximately 7 million early deaths every year worldwide and more than 3\% of disability-adjusted life years lost [15]. Air pollution has numerous harmful effects on health and contributes to the development and morbidity of cardiovascular disease, metabolic disorders, and a number of lung pathologies, including asthma and COPD [16]. To this end, air pollution is the world's most extensive single environmental risk, according to the World Health Organization.

Recently, it has been found that the number of patients with COPD who do not have a history of smoking is higher than expected [17], particularly female patients [18]. Emerging data indicate that air pollution exposure alters epigenetic markers, such as DNA methylation (DNAm) and that these changes may influence the expression of genes that control inflammation, disease development, and exacerbation risk $[19,20]$. Exposure to several traffic-related air pollution (TRAP) components, including particulate matter (PM), black smoke (BS), ozone ( $\left.\mathrm{O}_{3}\right)$, nitrogen oxides ( $\left.\mathrm{NOx}\right)$, and polyaromatic hydrocarbons has been associated with changes in DNAm in lung and other tissues [20,21]. Air pollution exposure can also stimulate pro-inflammatory immune responses, including T helper lymphocyte type 2 (Th2) and type 17 (Th17) adaptive responses, and dysregulate anti-viral immune responses $[22,23]$. The clinical effects of acute and chronic air pollution exposure, in particular the known association between elevated levels and exacerbations of asthma and COPD, are consistent with those identified in inflammatory and immunological mechanisms activated in the lung during disease processes [24]. For example, short-term exposure to air PM, nitrogen dioxide $\left(\mathrm{NO}_{2}\right)$, sulfur dioxide $\left(\mathrm{SO}_{2}\right)$, and carbon monoxide $(\mathrm{CO})$ can trigger a neutrophil-mediated airway inflammatory response, followed by increased clinical symptoms [25]. The deposition of PM in the respiratory tract depends predominantly on the size of the particles, with larger particles deposited in the upper and larger airways and smaller particles penetrating deep into the alveolar spaces. Ineffective clearance of PM from the airways could cause particle retention in lung tissue, resulting in a chronic, low-grade inflammatory responses that may be pathogenically important in both the exacerbation and progression of lung disease [26].

Globally, exposure to household indoor air pollution in women who do not smoke also occurs via inhalation of combustion products from biomass fuels, including wood, 
charcoal, animal dung, and others used for cooking $[27,28]$. Due to traditional gender roles, these exposures have significantly contributed to COPD morbidity and mortality in women [29]. It is estimated that $50 \%$ of households worldwide (about 3 billion people) are exposed to smoke from biomass fuel combustion. These exposures contribute to about half of the deaths from COPD in developing countries, of which $75 \%$ are women $[27,28]$.

\subsection{Exacerbation triggers}

Exacerbations of COPD are episodes of worsening of symptoms, leading to substantial morbidity and mortality [30]. COPD exacerbations are associated with increased airway and systemic inflammation and physiological changes, including hyperinflation. These are triggered mainly by respiratory viruses and bacteria, which infect the lower airway and increase airway inflammation. Some patients are particularly susceptible to exacerbations and show worse health status and faster disease progression than those who have infrequent exacerbations [31].

The mechanisms of COPD exacerbations are complex. While respiratory viruses (in particular rhinoviruses) and bacteria play a major role in their causative etiology [32], in some patients, noninfective environmental factors also contribute to their development. Data recently published from a large observational study identified a phenotype of patients that are more susceptible to frequent exacerbations from environmental exposures [33]. Other quantitative studies indicated that anxiety and depression could lead to a statistically significant increase in the likelihood of COPD patients being hospitalized [34]. Although more than $80 \%$ of exacerbations are managed on an outpatient basis, hospitalization is all too common and associated with considerable health care costs and mortality. In this regard, noninvasive ventilation has greatly decreased the mortality in exacerbations that require ventilatory support. However, across the range of exacerbation severity, treatment failure and relapses are frequent [35].

Among individuals with COPD, exposure to outdoor air pollutants is associated with loss of lung function and increased respiratory symptoms, leading to exacerbations and increased mortality [36]. Some studies suggest that temperature may modify the effect of air pollution exposure, although their results are not conclusive [37]. For example, Yan et al. explored the environmental effect of two different geographical places on COPD exacerbations (Beijing in summer, Sanya in winter) and found that poorer air quality index (AQI) and higher temperatures in Beijing were associated with lower FEV1, higher dyspnea, and a twice higher relative risk of exacerbations than in patients in Sanya [38]. The authors also reported that ambient air pollution was strongly associated with COPD exacerbations by triggering apoptosis in airway epithelial cells [38].

Although adequate evidence for a direct relationship between ambient air pollution components and the development of COPD is lacking, higher mortality rates from respiratory and cardiovascular diseases have been reported among patients exposed to air pollution for a very long time [19,39]. Several reports have also pointed out the possibility that acute exacerbations of COPD can be caused by short-term exposures to air pollutants $[25,40,41]$, as well as secondhand tobacco smoke [42].

Regarding sex differences in COPD exacerbations, the available literature indicates that outdoor air pollution affects lung function and triggers exacerbations in both male and female patients, but nonsmoker women may be more affected than men $[11,43,44]$. This indicates that air pollution may result in differential COPD exacerbation rates and outcomes in men vs. women. Data from multi-center studies have also shown that air pollution concentrations in the ambient are associated with declined lung function and increased risks for hospitalization and mortality in COPD patients. Because sex differences in AECOPD is an understudied area, in the current review, we investigated the association between exposure to gaseous and particulate pollutants and hospitalizations for COPD exacerbations, paying particular attention to differences between males and females. Other systematic reviews and meta-analyses have found that short-term exposures to air pollutants significantly increase the burden of risk of COPD acute exacerbations 
[4,45]. In the current study, we focus on the association of air pollution exposure and hospitalizations for COPD exacerbations with an emphasis on sex differences. Therefore, we selected studies that included both male and female participants, including those that did or did not analyze outcomes by sex.

\section{Materials and Methods}

\subsection{Literature Search, Databases and Key Terms Searched}

We used PubMed and Google Scholar to search for articles related to our study's focus, using the following search terms: "air pollution", "COPD", "COPD exacerbation", "hospital admission", and "sex". The search was limited to epidemiological studies from 2000 to 2020, although we also included articles prior to 1990 if they contained relevant information. We focused on articles that pooled results on a global scale, reported analytical pooled estimates, were written in English or with an English abstract and studied associations between air pollution and hospitalization for COPD exacerbation as well as respiratory response to shorter-term exposure of air pollution.

\subsection{Inclusion Criteria}

The literature search was limited to human epidemiological studies on (1) Hospitalization due to acute exacerbation of COPD, as identified by the International Statistical Classification of Diseases, 10th Revision (ICD-10) codes J40-J44; (2) A diagnosis of COPD; and presentation for treatment of acute exacerbations of COPD (AECOPD), as defined by increasing shortness of breath, worsening cough, or change in sputum production at presentation; (3) Research-data based; (4) From adult patients (age > 18 years); and (5) published in English language.

\subsection{Search Process and Study Selection}

PubMed and Google Scholar were the main databases utilized. Records were de-duplicated using built-in mechanisms of university library services (Covidence software) and further completed manually. Articles were then screened by their titles and abstracts for inclusion or exclusion. Final selections were determined after full reading of articles.

\subsection{Data Extraction and Analysis}

We extracted information on the association between daily mean concentrations of particulate matter of a diameter of less than $10 \mu \mathrm{m}\left(\mathrm{PM}_{10}\right)$ or $2.5 \mu \mathrm{m}\left(\mathrm{PM}_{2.5}\right)$ as well as other gas pollutants $\left(\mathrm{O}_{3}, \mathrm{CO}, \mathrm{NO}_{2}, \mathrm{SO}_{2}\right)$ with hospital admissions, analyzing the sex variable, based on daily measurements reported in each study or other data that could be aggregated into daily mean values. Thus, results are presented as associations of 24-hour average air pollutant concentrations and daily hospital admissions for AECOPD.

\section{Results}

\subsection{Selected studies}

A flow chart of the literature search is shown in Figure 1. The search string returned 8,302 potentially relevant article citations. After systematically reviewing all the abstracts, 7,014 irrelevant studies and 1,083 duplicates were removed. The two authors independently reviewed the remaining 205 full articles for inclusion. After full-text revision, 40 articles were included for systematic analysis and are summarized in Table 1. Combined, these articles reported a total of 2,329,320 hospital admissions for AECOPD, with an average of 58,233 hospitalizations per study ranging from 40 to 578,006 and a standard 
deviation of 134,419 . Hospitalizations for AECOPD in the selected studies spanned four different continents, and the statistics per continent are shown in Figure 2.

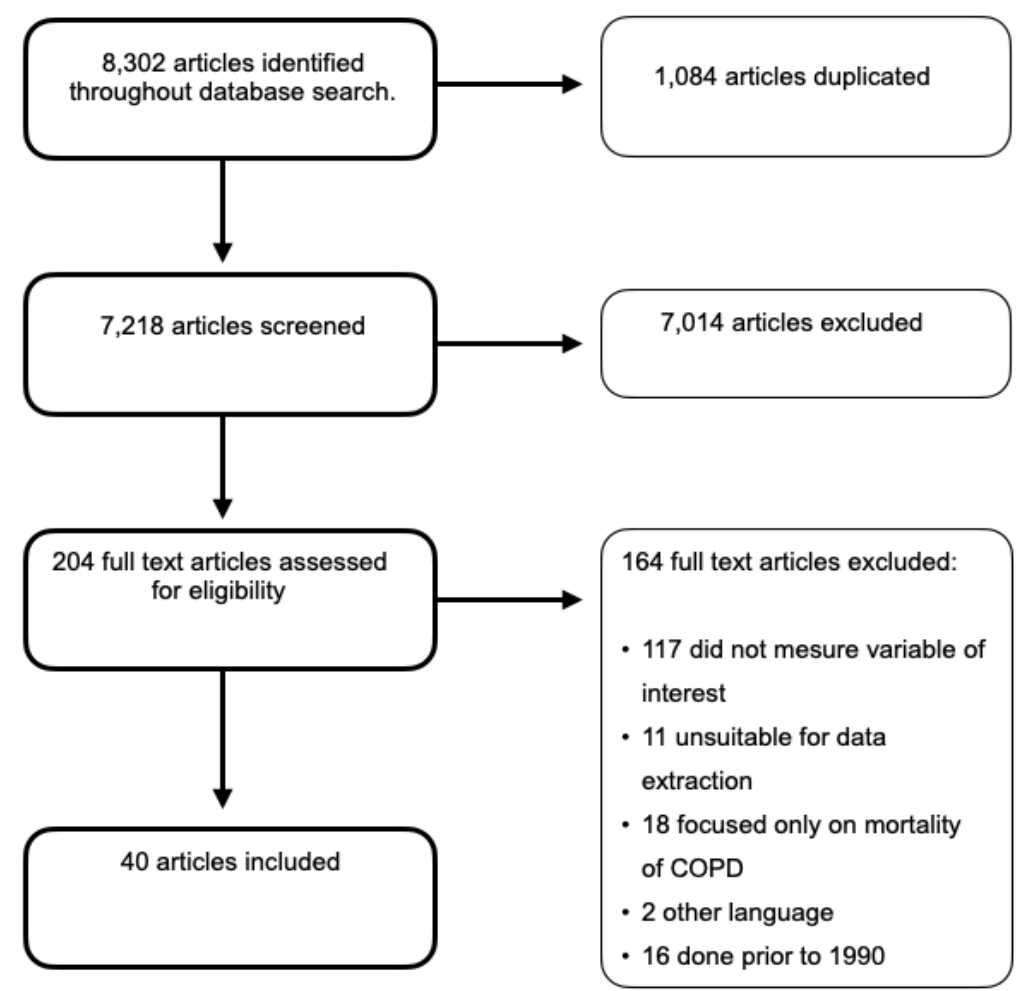

Figure 1. Literature search flow for this study.

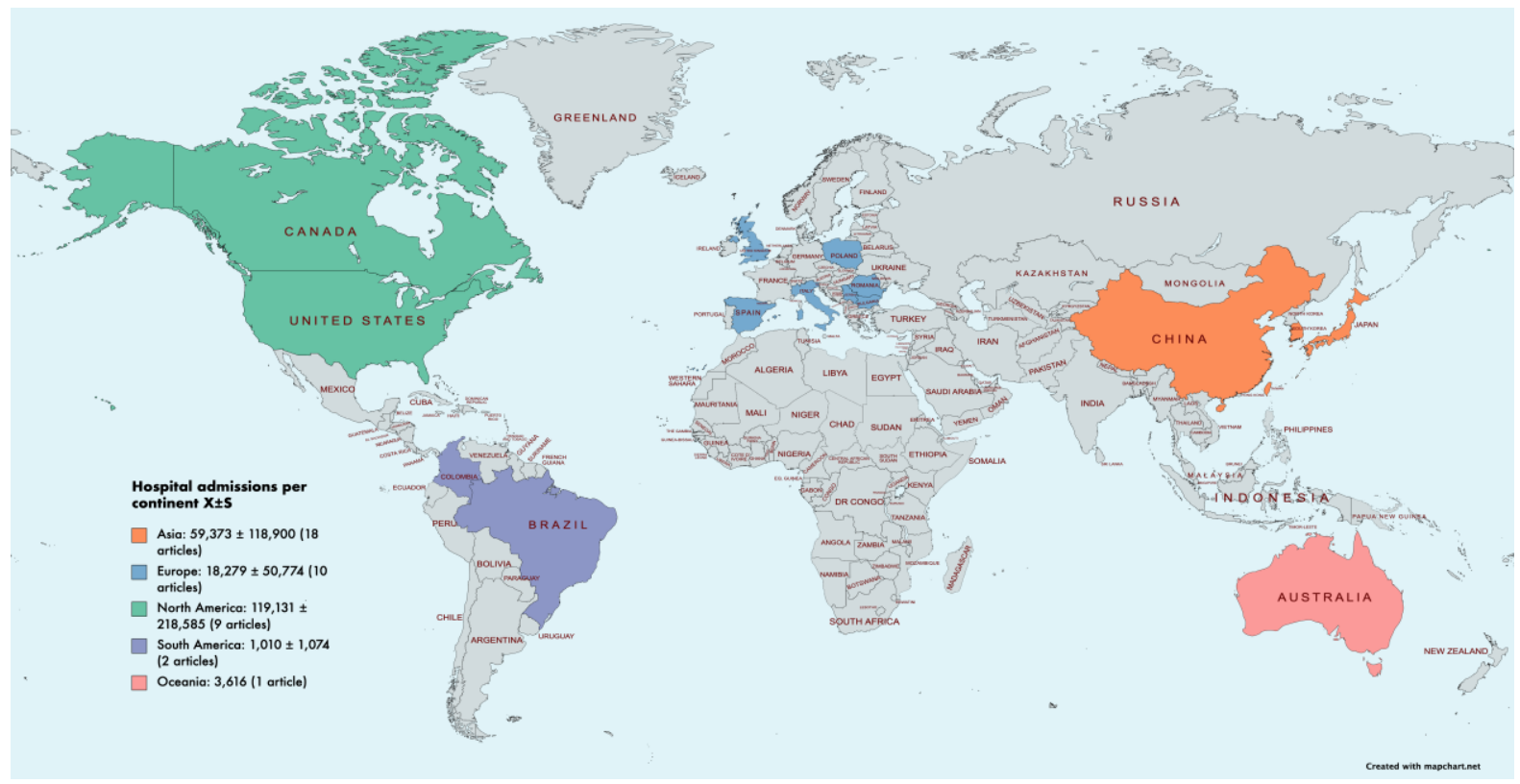

Figure 2. Geographical distribution of studies assessing hospitalization for AECOPD due to air pollution. 


\subsection{Individual and combined air pollutant concentrations and their association to daily hospital admissions for AECOPD}

Table 1 summarizes the effects of air pollution of exposure in AECOPD in 40 studies. Regardless of geographical location, most studies identified a significant association between particulate pollution exposure and AECOPD. The incremental increases in concentrations of $\mathrm{PM}_{2.5}$ and $\mathrm{PM}_{10}$ were significantly associated with increased risk of hospitalization of AECOPD [40,46], but also stroke and myocardial infarction. However, the adverse influences of $\mathrm{PM}_{2.5}$ on these diseases were generally more robust than those of PM10 [47]. In the US mid-Atlantic states, PM2.5 exposure was associated with all COPD hospital admissions, with a relative risk increase of 1.83 for every $10 \mu \mathrm{g} / \mathrm{m}^{3}$ increase in $\mathrm{PM}_{2.5}$ [46]. In Central and Eastern Europe, increases in hospital admissions were reported as 3.3\% and $2.8 \%$ for $\mathrm{PM}_{10}$ and $\mathrm{PM}_{2.5}$, respectively [48].

When assessing the effects of gaseous air pollutants on AECOPD, it was found that $\mathrm{SO}_{2}$ increases of $10 \mu \mathrm{g} / \mathrm{m}^{3}$ were related to a $6 \%$ increase in hospital admissions for chronic bronchitis, with a two-day lag [49]. Comparably, an independent air pollution modeling study found that when modeled jointly with other pollutants, only $\mathrm{SO}_{2}$ remained significantly associated with AECOPD (hazard ratio 1.038), although the five pollutants assessed in this study were highly correlated $(r=0.89)$ [48]. In addition, short-term exposures to $\mathrm{SO}_{2}$ were associated with an increase in COPD exacerbation risk, with an odds ratio (OR) of 2.45 per $1 \mathrm{ppb}$ increase in $\mathrm{SO}_{2}$ levels, after adjustment for $\mathrm{PM}_{2.5}$ in a region with a relatively low AQI (central Massachusetts, USA) [41]. Regarding $\mathrm{NO}_{2}$ and $\mathrm{CO}$, both were significantly associated with AECOPD hospitalizations [50]. Tellingly, the magnitude of effects was expanded slightly with increasing days of exposure, with a relative risk of 1.11 and 1.08 for $\mathrm{NO}_{2}$ and $\mathrm{CO}$, respectively, for a 7-day exposure average [50]. Likewise, a study in South Korea found that each $10 \mu \mathrm{g} / \mathrm{m}^{3}$ increase in $\mathrm{CO}$ was associated with a $2 \%$ increase in the odds of admission for AECOPD [51].

In multi-pollutant exposure models, significant associations between hospital admissions for COPD were found for all five air pollutants $\left(\mathrm{SO}_{2}, \mathrm{NO}_{2}, \mathrm{O}_{3}, \mathrm{PM}_{10}, \mathrm{PM}_{2.5}\right)$, with relative risks for admission for every $10 \mu \mathrm{g} / \mathrm{m}^{3}$ increase of $\mathrm{SO}_{2}=1.007, \mathrm{NO}_{2}=1.026, \mathrm{O}_{3}=$ 1.034, $\mathrm{PM}_{10}=1.024$, and $\mathrm{PM}_{2.5}=1.031$, respectively, at a lag day ranging from lag 0 to cumulative lag 0-5 [52]. PM10 and $\mathrm{SO}_{2}$ were associated with both acute and lagged effects on emergency department visits due to COPD, with interquartile range increases in $28.3 \mu \mathrm{g} / \mathrm{m}^{3}$ and $7.8 \mu \mathrm{g} / \mathrm{m}^{3}$, respectively, associated with a cumulative 6-day increase of $19 \%$ and $16 \%$ in COPD admissions, respectively [53]. In addition, declines in attributable hospital admissions for AECOPD were associated with a reduction in concentrations of PM2.5, $\mathrm{PM}_{10}, \mathrm{SO}_{2}$, and $\mathrm{O}_{3}[54]$.

Finally, other environmental factors have been found to contribute to AECOPD in the studies analyzed. For example, the COPD-related emergency room admissions for all age groups were significantly associated with previous-day BS levels, and lag 0-2 (1.60\% and $2.26 \%$ increase per $10 \mu \mathrm{g} / \mathrm{m}^{3}$, respectively) in a study conducted in Serbia [55]. Similarly, a study in Guangzhou, China, found that haze (at lag1) and air pollution ( $\mathrm{NO}_{2}$ at lag 5 and $\mathrm{SO}_{2}$ at lag 3 combined presented more drastic effects on patients aged 19-64, especially in females [56]. Increases in $\mathrm{NO}_{2}$ were associated with the highest risk of hospital admissions for total and respiratory diseases in both single- and multi-pollutant models, and a relative risk of 1.94 in ER at lag 0 for COPD patients [56]. Relative risks at lag0 ranged from 1.018 to 1.036 for each interquartile range increase in air pollution concentration. These increased risks became non- significant by lag4 [56]. 
Table 1. Studies reporting acute exacerbation of COPD due to air pollution exposure

\begin{tabular}{|c|c|c|c|c|c|c|}
\hline Reference & Study Type & Pollutants & $\begin{array}{l}\text { Period \& } \\
\text { Location }\end{array}$ & $\begin{array}{c}\text { Total sample } \\
\text { (N) } \\
\text { M:F } \\
\text { Age }\end{array}$ & $\begin{array}{l}\text { Measured } \\
\text { Outcome }\end{array}$ & Main Findings \\
\hline
\end{tabular}

\begin{tabular}{|c|c|c|c|c|c|c|}
\hline $\begin{array}{l}\text { Ko et al., } \\
2007 \text { [52] }\end{array}$ & $\begin{array}{c}\text { Time-series } \\
\text { study }\end{array}$ & $\begin{array}{c}\mathrm{PM}_{2.5}, \mathrm{PM}_{10} \\
\mathrm{CO}_{2} \mathrm{SO}_{2} \\
\mathrm{NO}_{2}, \mathrm{O}_{3}\end{array}$ & $\begin{array}{c}\text { 2000-2004 } \\
\text { Hong } \\
\text { Kong }\end{array}$ & $\begin{array}{c}\text { 119,225, } \\
\text { M:F(N/A) } \\
>18 \text { years }\end{array}$ & $\begin{array}{c}\text { Hospital } \\
\text { Admissions }\end{array}$ & $\begin{array}{l}\text { Ambient concentrations of air pol- } \\
\text { lutants increased hospital admis- } \\
\text { sions for COPD, especially during } \\
\text { the winter season (December- } \\
\text { March), where indoor exposure to } \\
\text { air pollution was higher. }\end{array}$ \\
\hline
\end{tabular}

\begin{tabular}{|c|c|c|c|c|c|c|}
\hline $\begin{array}{l}\text { Kloog et } \\
\text { al.,2014 } \\
{[46]}\end{array}$ & $\begin{array}{l}\text { Case-crosso- } \\
\text { ver analysis }\end{array}$ & $\mathrm{PM}_{2.5}$ & $\begin{array}{c}\text { 2000-2006 } \\
\text { United } \\
\text { States }\end{array}$ & $\begin{array}{c}416,778 \\
176,314 \\
M: 240,464 \mathrm{~F} \\
\geq 65 \text { years }\end{array}$ & $\begin{array}{c}\text { Hospital } \\
\text { Admissions }\end{array}$ & $\begin{array}{c}\mathrm{PM}_{2.5} \text { exposure was associated with } \\
\text { all COPD hospital admissions with } \\
\text { an increased RR of } 1.83 \text { for every } \\
10 \mu \mathrm{g} / \mathrm{m}^{3} \text { increase in } \mathrm{PM}_{2.5} \text {. }\end{array}$ \\
\hline
\end{tabular}

$\begin{array}{lccccc}\text { Leitte } e t & \text { Time-series } & \mathrm{TSP}, \mathrm{SO}_{2}, & 2001-2002 & 671 & \text { Hospital } \\ \text { al.,2009 } & \text { study } & \mathrm{NO}_{2} & \text { Romania } & \mathrm{M}: \mathrm{F}(\mathrm{N} / \mathrm{A}) & \text { Admissions } \\ {[49]} & & & >18 \text { years } & \text { \& Mortality }\end{array}$

Chronic bronchitis was associated with particulate matter and mainly $\mathrm{SO}_{2}$, and dry air aggravates the adverse effect of particulate matter.

\begin{tabular}{|c|c|c|c|c|c|}
\hline $\begin{array}{l}\text { Arbex et } \\
\text { al.,2009 } \\
\text { [53] }\end{array}$ & $\begin{array}{c}\text { Time-series } \\
\text { study }\end{array}$ & $\begin{array}{c}\mathrm{PM}_{10}, \mathrm{CO}, \\
\mathrm{SO}_{2}, \mathrm{NO}_{2}, \\
\mathrm{O}_{3}\end{array}$ & $\begin{array}{c}\text { 2001-2003 } \\
\text { Brazil }\end{array}$ & $\begin{array}{c}1,769 \\
975 \text { M:794 F } \\
\geq 40 \text { vears }\end{array}$ & $\begin{array}{c}\text { Hospital } \\
\text { Admissions }\end{array}$ \\
\hline
\end{tabular}

$\mathrm{PM}_{10}$ and $\mathrm{SO}_{2}$ readings showed both acute and lagged effects on COPD ED visits. Increases in $\mathrm{CO}$ concentration showed impacts in the female and elderly groups.

$\begin{array}{lccccc}\text { Tao } \text { et } & \text { Time-series } & \mathrm{PM}_{10}, \mathrm{SO}_{2}, & 2001-2005 & 5,301 & \text { Hospital } \\ \text { al.,2014 } & \text { study } & \mathrm{NO}_{2} & \text { China } & \mathrm{M} 3,663: \mathrm{F} \mathrm{1,638} & \text { Admissions } \\ {[58]} & & & >18 \text { years } & \end{array}$

$\begin{array}{lccccc}\text { Tian } \text { et } & \text { Time-series } & \mathrm{PM}_{2.5, \mathrm{CO}}, & 2001-2007 & 117,329 & \text { Hospital } \\ \text { al.,2014 } & \text { study } & \mathrm{NO}_{2} & \text { Hong } & \text { M:F(N/A) } & \text { Admissions } \\ {[59]} & & & \text { Kong } & >18 \text { years } & \end{array}$

There were significant associations between air pollutants exposure and respiratory hospital admissions, and stronger effects were observed for females and patients aged $\geq 65$ years

Ambient $\mathrm{CO}$ was negatively associated with the risk of hospitalizations for COPD. After adjustment for $\mathrm{NO}_{2}$ or $\mathrm{PM}_{2.5}$ levels, the negative associations of $\mathrm{CO}$ with COPD hospitalizations became stronger. 


$\begin{array}{lccccc}\text { Miluti- } & \text { Time-series } & \mathrm{BS}, \mathrm{SO}_{2} & 2002-2003 & 4,572 & \text { Hospital } \\ \text { nović et } & \text { study } & & \text { Serbia } & \text { M:F(N/A) } & \text { Admissions } \\ \text { al.,2009 } & & & >18 \text { years } & \\ {[55]} & & & & \end{array}$

The ED admissions for all ages for COPD were significantly associated with previous-day levels of BS and lag 0-2. After controlling for $\mathrm{SO}_{2}$, single lagged (lag 1 and lag 2) as well as mean lagged values of BS (up to lag 0-3) were significantly associated with COPD ED visits.

\begin{tabular}{|c|c|c|c|c|c|}
\hline $\begin{array}{l}\text { Chen et } \\
\text { al.,2004 } \\
\end{array}$ & $\begin{array}{c}\text { Time-series } \\
\text { study }\end{array}$ & $\mathrm{PM}_{2.5}, \mathrm{PM}_{10}$ & $\begin{array}{c}\text { 1995-1999 } \\
\text { Canada }\end{array}$ & $\begin{array}{c}4,409 \\
\mathrm{M}: \mathrm{F}(\mathrm{N} / \mathrm{A}) \\
\geq 65 \text { years }\end{array}$ & $\begin{array}{l}\text { Hospital } \\
\text { Admission }\end{array}$ \\
\hline
\end{tabular}

PM measures were significantly associated with COPD hospitalization in areas where the level of air pollution are relatively low. The effects were not independent of other air pollutants.

To et

al.,2015

[61]

Cho et

al.,2014

[51]

Case-crosso-

ver analysis

$\begin{array}{cc}\mathrm{PM}_{10}, \mathrm{CO}, & \text { 2005-2009 } \\ \mathrm{SO}_{2}, \mathrm{NO}_{2}, & \text { Korea } \\ \mathrm{O}_{3} & \end{array}$

842

$\mathrm{M}: \mathrm{F}(\mathrm{N} / \mathrm{A})$

$>18$ years

21,334

$\mathrm{M}: \mathrm{F}(\mathrm{N} / \mathrm{A})$

$>18$ years

Hospital

Admissions

Hospital

Admissions

s
positively associated with ED visits for depressive episodes in each disease strata with the exception of COPD. $\mathrm{SO}_{2}, \mathrm{PM}_{10}, \mathrm{NO}_{2}$, and $\mathrm{CO}$ significantly increased the risk of ED visits for depressive episodes, especially among individuals with pre-existing cardiovascular disease, diabetes mellitus, or asthma.

$\begin{array}{lccccc}\text { Sauerzapf } & \text { Case-crosso- } & \mathrm{PM}_{2.5, \mathrm{CO}}, & 2006-2007 & 1,050 & \text { Hospital } \\ \text { et al.,2009 } & \text { ver analysis } & \mathrm{NO}_{2}, \mathrm{NOx}, & \text { England } & \mathrm{M}: \mathrm{F}(\mathrm{N} / \mathrm{A}) & \text { Admissions } \\ {[62]} & & \mathrm{O}_{3} & & >18 \text { years } & \end{array}$

$\begin{array}{lc}\text { Cai } \text { et } & \text { Time-series } \\ \text { al.,2015 } & \text { study }\end{array}$

CO 2006-2008
China
121,463 $\mathrm{M}: \mathrm{F}(\mathrm{N} / \mathrm{A})$ $>18$ years
Among a population of a less urbanized area, this study found evidence that ambient pollutant concentrations were still associated with the risks of hospital admission for COPD.

Hospital
Admissions

Negative associations were found between ambient $\mathrm{CO}$ concentrations and daily COPD hospitalization. An interquartile range increase of $0.6 \mathrm{mg} / \mathrm{m}^{3}$ in CO concentration at lag 3 day corresponded to $-2.97 \%$ (95\% confidence interval: $-4.63 \%,-1.31 \%$ ) change in COPD hospitalization. Short-term exposure to $\mathrm{CO}$ at low ambient 


$\begin{array}{lccccc}\begin{array}{l}\text { Yorifuji et } \\ \text { al.,2014 }\end{array} & \begin{array}{c}\text { Case-crosso- } \\ \text { ver analysis }\end{array} & \begin{array}{c}\mathrm{SPM}_{1} \mathrm{O}_{3}, \\ \mathrm{SO}_{2}\end{array} & \begin{array}{c}2006-2010 \\ \text { Japan }\end{array} & \begin{array}{c}767 \\ \mathrm{M}: \mathrm{F}(\mathrm{N} / \mathrm{A})\end{array} & \begin{array}{c}\text { Hospital } \\ \text { Admissions }\end{array} \\ {[64]} & & & & \geq 65 \text { years } & \end{array}$

Schikowski Case-crossoet al.,2014 ver analysis [65]

Zhang et
al.,2014

[56]

$\begin{array}{lc}\text { Yan et } & \text { Comparative } \\ \text { al.,2019 } & \text { study }\end{array}$

[66]

Liang et

al.,2019

[67]

\begin{abstract}
Time-series
study
\end{abstract}
Haze, $\mathrm{SO}_{2}, \quad$ 2008-2011
$\mathrm{NO}_{2}$
China

2006-2010
Taiwan

10,242

4,348 M:5,894 F

$>18$ years

Hospital

Admissions

$\begin{array}{cccc}\text { PM, NOx } & 2006-2010 & 10,242 & \text { Hospital } \\ \text { Taiwan } & 4,348 \text { M:5,894 F } & \text { Admissions } \\ & >18 \text { years } & \end{array}$

1,380

$\mathrm{M}: \mathrm{F}$ (N/A)

$>18$ years
Hospital
Admissions
PM, CO 2016-2018
China

139

$48 \mathrm{M}: 91 \mathrm{~F}$

$>18$ years

161,613

$\mathrm{M}: \mathrm{F}(\mathrm{N} / \mathrm{A})$

$>18$ years
Hospital Admissions

Hospital Admissions

$\begin{array}{cccc}\text { Ecological } & \mathrm{PM}_{2.5}, \mathrm{PM}_{10}, & 2013-2017 & 161,613 \\ \text { analysis } & \mathrm{CO}_{2} \mathrm{SO}_{2}, & \text { China } & \mathrm{M}: \mathrm{F}(\mathrm{N} / \mathrm{A}) \\ & \mathrm{NO}_{2}, \mathrm{O}_{3} & & >18 \text { years }\end{array}$

concentration may be associated with reduced risk of COPD hospitalization.

SPM exposure 24 to $<72$ hours prior to the onset, and $\mathrm{O}_{3}$ exposure 48 to $<96$ hours prior to the onset were associated with increased risk of respiratory disease. Hourly changes in air pollution exposure increased the risk of respiratory disease, and $\mathrm{SO}_{2}$ may be related with more immediate effects than other pollutants.

The only statistically significant associations were observed in females (COPD prevalence using GOLD: OR 1.57, 95\% CI 1.11-2.23; and incidence: OR 1.79, 95\% CI 1.21-2.68). None of the principal results were statistically significant.

$\mathrm{NO}_{2}$ was the sole pollutant with the largest risk of hospital admissions for total and respiratory diseases in both single- and multi-pollutant models and both presented more drastic effects on the 19 to 64 years old and in females. Haze pollution was associated with total and cardiovascular illnesses.

These findings suggested that ambient air pollution causes COPD exacerbation, and that PM exposure induces apoptosis of airway epithelial cells.

Increased acute air pollution episodes were significantly associated with increased hospitalizations for

AECOPD with women and patients aged $>65$ years showing the highest susceptibility and hospitalization risk. 


$\begin{array}{lccccc}\text { Hendryx et } & \text { Longitudinal } & \mathrm{PM}_{2.5,} \mathrm{PM}_{10}, & 2000-2019 & 3616 & \text { New COPD } \\ \text { al.,2019 } & \text { study } & \mathrm{CO}_{2} \mathrm{SO}_{2}, & \text { Australia } & \text { all female } & \text { cases } \\ {[48]} & & \mathrm{NO}_{2} & & >18 \text { years } & \end{array}$

$\begin{array}{ll}\text { DeVries et } & \text { Case-crosso- } \\ \text { al.,2016 } & \text { ver analysis }\end{array}$

[41]

\section{Du et}

al.,2021

[68]

\section{Lin $e t$ \\ al.,2018}

[69]

\begin{abstract}
Case-crosso-
ver analysis
\end{abstract}

$\mathrm{NO}_{2}, \mathrm{CO}$,

2011-2015

$\mathrm{SO}_{2}, \mathrm{PM}_{10}$,

Taiwan

2019

$\mathrm{PM}_{10}, \mathrm{PM}_{2.5}$,

$\mathrm{O}_{3}, \mathrm{NO}_{2}$
168

$57 \mathrm{M}: 101 \mathrm{~F}$

$\geq 65$ years
Hospital

Admissions

\section{1,563 Hospital \\ 1,277 M:286 F $\geq 65$ years \\ Admissions}

277

$240 \mathrm{M}: 37 \mathrm{~F}$

$\geq 65$ years
Hospital

Admissions
Sinharay et

al.,2017

[70]
Randomized, crossover study

$\begin{array}{cc}\mathrm{BC}, \mathrm{NO}_{2}, & 2012-2014 \\ \mathrm{PM}_{10}, \mathrm{PM}_{2.5}, & \text { United } \\ \text { UFP } & \text { Kingdom }\end{array}$

40

$19 \mathrm{M}: 21 \mathrm{~F}$

$\geq 60$ years
Respiratory

response to shorterterm exposure of air pollution
Controlling for covariates, all five air pollutants modeled individually were significantly associated with risk of COPD. Multiple exposure sources and pollutants contributed to COPD risk, including electricity generation and mining but extending to many industrial processes.

Short-term exposures to $\mathrm{SO}_{2}$ were associated with an increase in COPD exacerbation risk OR 2.45 (95 \% CI: 1.75-3.45 per 1 ppb increase) after adjustment for $\mathrm{PM}_{2.5}$. Despite living in areas with air pollution concentrations below current USEPA NAAQS, these COPD patients appeared to suffer increased risk of COPD exacerbation following short-term exposures to increased $\mathrm{SO}_{2}$ and $\mathrm{NO}_{2}$ levels.

The concentrations of 6 monitored pollutants and AECOPD hospitalizations showed statistically significant spatial clustering. After adjusting for potential confounders, residential $\mathrm{SO}_{2}, \mathrm{NO}_{2}$ and $\mathrm{O}_{3}$ concentrations were significantly associated with increased AECOPD hospitalizations. Ambient air pollution was spatially correlated with AECOPD hospitalizations.

Increased $\mathrm{NO}_{2}, \mathrm{CO}, \mathrm{O}_{3}$ and $\mathrm{PM}_{10}$ concentrations and continual temperature changes (colder during cooling-down seasons or hotter during warming-up seasons) were associated with AE COPD in older patients.

Participants with COPD reported more cough (OR 1.95, 95\% CI 0.963.95), sputum (OR 3.15, 95\% CI 1.39-7.13), shortness of breath (OR $1 \cdot 86,95 \%$ CI 0.97-3.57), and wheeze (OR 4.00, 95\% CI 1.52-10.50) after walking down Oxford Street (high traffic pollution) compared with Hyde Park (low traffic pollution). 


\begin{tabular}{|c|c|c|c|c|c|c|}
\hline $\begin{array}{l}\text { Wang et } \\
\text { al.,2021 } \\
{[54]}\end{array}$ & $\begin{array}{l}\text { Ecological } \\
\text { study }\end{array}$ & $\begin{array}{l}\mathrm{PM}_{2.5}, \mathrm{PM}_{10} \\
\mathrm{PMcoarse} \\
\mathrm{SO}_{2}, \mathrm{NO}_{2} \\
\mathrm{CO}, \mathrm{O}_{3}\end{array}$ & $\begin{array}{c}\text { 2013-2017 } \\
\text { China }\end{array}$ & $\begin{array}{c}483,861 \\
\text { M:F(N/A) } \\
>18 \text { years }\end{array}$ & $\begin{array}{c}\text { Hospital } \\
\text { Admissions }\end{array}$ & $\begin{array}{l}\text { Reduction in PM may result in de- } \\
\text { clined attributable hospitalizations } \\
\text { for AECOPD, while } \mathrm{O}_{3} \text { is an im- } \\
\text { portant risk factor following an in- } \\
\text { tervention. }\end{array}$ \\
\hline
\end{tabular}

Chen et al.,2020 [71]

Time-series
study
$\mathrm{PM}_{2.5}, \mathrm{PM}_{10}$ $\mathrm{O}_{3}$
2014-2017
China

17,655

9,234 M:8,421 F

$>18$ years

Hospital

Air pollution increased the rate of hospitalization for AECOPD. The risk of hospitalization for AECOPD in the age $\geq 65$ group was greater than age $<65$ group for all day lags. The risk of male and female hospitalizations for AECOPD after lag3-lag5 was higher than that after lag0-lag2, and the strongest risk of hospitalizations for both was with lag3. $\begin{array}{lc}\text { Zieliński et } & \text { Time-series } \\ \text { al.,2018 } & \text { study }\end{array}$

[72]

Gutierrez

et al.,2020

[73]

Chen et

al.,2019

[47]

Prospective

cohort study
Time-series study

PM2.5, PM10 $_{10}$ 2006-2016
Poland

12,889

$7968 \mathrm{M}: 4921 \mathrm{~F}$

$\geq 65$ years

Hospital

Admissions

PM2.5

2013-2016
United
States

296

290 M:6 F

$\geq 65$ years

$\mathrm{PM}_{2.5}, \mathrm{PM}_{10}$,
$\mathrm{SO}_{2}, \mathrm{NO}_{2}$,

$\mathrm{O}_{3}$

2013-2015
China

6,981

4,920 M:2,061 F

$\geq 65$ years
Hospital
Admissions

Hospital

Admissions
No connection between PM10 concentration and COPD exacerbations were observed. The PM2.5 influence was significant beginning on 14 day before admission (RR 1.06) and increased up to a maximal studied period of 90 days (RR 1.32).

Saharan dust outbreaks observed in Miami elevated the concentration of PM and increased the risk of AECOPD in patients with recurrent exacerbations.

The incremental increased concentrations of $\mathrm{PM}_{2.5}$ and PM10 were significantly associated with increased risk of hospitalization of AECOPD, stroke, and $\mathrm{MI}$, and the adverse influences of PM2.5 on these diseases were generally stronger than that of PM10 in Jinan, China.

\begin{tabular}{lccccc} 
Chen et & Time-Series & $\mathrm{PM}_{2.5}, \mathrm{PM}_{10}$, & $2014-2018$ & 17,592 & Hospital \\
al.,2019 & study & $\mathrm{SO}_{2}, \mathrm{NO}_{2}$, & China & $9,196 \mathrm{M}: 8,396 \mathrm{~F}$ & Admissions \\
{$[74]$} & $\mathrm{O}_{3}$ & \multicolumn{3}{c}{$>18$ years } &
\end{tabular}

Air pollution, relative humidity, and temperature increased the risk of admission for AECOPD. The effect of $\mathrm{O}_{3}$ on the admission rate in male group was higher than that in the female group. Ambient air pollution had a weak influence on the age $\leq 50$ group. 


\begin{tabular}{|c|c|c|c|c|c|c|}
\hline $\begin{array}{l}\text { Kwon et } \\
\text { al.,2020 } \\
{[75]}\end{array}$ & Cohort study & $\mathrm{PM}_{10}, \mathrm{NO}_{2}$ & $\begin{array}{c}\text { 2012-2017 } \\
\text { Korea }\end{array}$ & $\begin{array}{c}296 \\
\text { 238 M:58 F } \\
\geq 65 \text { years }\end{array}$ & $\begin{array}{l}\text { Respiratory } \\
\text { response to } \\
\text { shorter- } \\
\text { term expo- } \\
\text { sure of air } \\
\text { pollution }\end{array}$ & $\begin{array}{l}\text { Long-term exposure to } \mathrm{PM}_{10} \text { corre- } \\
\text { lated with both lung function and } \\
\text { COPD-relevant imaging pheno- } \\
\text { types in a Korean cohort. }\end{array}$ \\
\hline $\begin{array}{l}\text { Pini et } \\
\text { al.,2021 } \\
{[40]}\end{array}$ & $\begin{array}{c}\text { Time-series } \\
\text { study }\end{array}$ & $\mathrm{PM}_{2.5}, \mathrm{PM}_{10}$ & $\begin{array}{c}\text { 2014-2016 } \\
\text { Italy }\end{array}$ & $\begin{array}{c}431 \\
\text { M:F(N/A) } \\
\text { Age: N/A }\end{array}$ & $\begin{array}{c}\text { Hospital } \\
\text { Admissions }\end{array}$ & $\begin{array}{l}\text { Short-term increases in exposure to } \\
\text { PM10 or PM } 2.5 \text { were associated with } \text { a higher risk of ED admission and } \\
\text { hospitalization due to AECOPD } \\
\text { with a greater incidence during the } \\
\text { winter season. }\end{array}$ \\
\hline
\end{tabular}

$\begin{array}{lcccc}\begin{array}{l}\text { Reid } e t \\ \text { al.,2019 }\end{array} & \text { Cohort study } & \mathrm{PM}_{2.5,} \mathrm{O}_{3} & 2008 & 4,614 \\ {[76]} & & \text { United } & \text { M:F(N/A) } \\ & & & \text { States } & >18 \text { years }\end{array}$

Hospital
Admissions

Hospital

Admissions

\& mortality

M:26,740 F

$\geq 65$ years

2011

Serbia

270

$181 \mathrm{M}: 89 \mathrm{~F}$

(>18 years)

[78]
$\mathrm{PM}_{2.5}, \mathrm{PM}_{10}$

retrospective study

[33]

Doneva et al.,2019

[30]
Multi-center, prospective, one-year observational study
2016-2017

Colombia

250

103 M:147 F $\geq 65$ years

426

296 M:130 F

$>18$ years
Hospital Admissions

Hospital Admissions

Hospital Admissions

There were more ED visits than hospitalizations during the study period. For $\mathrm{PM}_{2.5}$, increasing risk of asthma hospitalizations with increasing quintiles of exposure was found in the PM2.5 -only model and the mutually adjusted model. ED visits for asthma, and COPD increased with increasing quintiles of $\mathrm{PM}_{2.5}$ exposure.

Significant associations of temperature, humidity, $\mathrm{O}_{3}, \mathrm{CO}, \mathrm{PM}_{10} \mathrm{NO}_{2}$ with hospital admissions were identified.

The number of days with high levels of $\mathrm{PM}_{2.5}$ per month was significantly associated with the total number of exacerbations (moderate and severe) for both asthma and COPD episodes among female and obese patients.

Patients with AECOPD have a higher median of particulate matter $48 \mathrm{hrs}$. prior to symptomatic onset, as well as greater use of antibiotics and corticosteroids.

Air pollution exposure led to an increased number of exacerbations and hospital stays. Patients with mild COPD had an average of 0.86 exacerbations and 2.61 days in hospital per year, while in those with severe COPD these values were 4 times higher. Outside pollution led to worsening of the disease 


\begin{tabular}{|c|c|c|c|c|c|c|}
\hline $\begin{array}{l}\text { Peacock et } \\
\text { al.,2011 } \\
{[79]}\end{array}$ & Cohort study & $\begin{array}{l}\mathrm{NO}_{2}, \mathrm{O}_{3}, \\
\mathrm{SO}_{2}, \mathrm{PM}_{10} \\
\quad \mathrm{BS}\end{array}$ & $\begin{array}{l}\text { 1995-1997 } \\
\text { United } \\
\text { Kingdom }\end{array}$ & $\begin{array}{c}94 \\
\text { All male } \\
\geq 40 \text { years }\end{array}$ & $\begin{array}{l}\text { Respiratory } \\
\text { response to } \\
\text { shorter- } \\
\text { term expo- } \\
\text { sure of air } \\
\text { pollution }\end{array}$ & $\begin{array}{l}\text { Outdoor air pollution was associ- } \\
\text { ated with adverse effects on symp- } \\
\text { toms in patients with COPD. }\end{array}$ \\
\hline $\begin{array}{l}\text { Medina- } \\
\text { Ramón et } \\
\text { al.,2006 } \\
{[80]}\end{array}$ & $\begin{array}{l}\text { Case-crosso- } \\
\text { ver study }\end{array}$ & $\mathrm{O}_{3}, \mathrm{PM}_{10}$ & $\begin{array}{l}\text { 1986-1999 } \\
\text { United } \\
\text { States }\end{array}$ & $\begin{array}{c}578,006 \\
\text { M:F(N/A) } \\
\geq 65 \text { years }\end{array}$ & $\begin{array}{c}\text { Hospital } \\
\text { Admissions }\end{array}$ & $\begin{array}{c}\text { Exposure to } \mathrm{O}_{3} \text { and } \mathrm{PM}_{10} \text { was asso- } \\
\text { ciated with respiratory-related hos- } \\
\text { pital admissions. The effect of air } \\
\text { pollution was modified by city } \\
\text { characteristics like meteorology, } \\
\text { pollution sources, and socioeco- } \\
\text { nomic factors. }\end{array}$ \\
\hline
\end{tabular}

$\begin{array}{lccccc}\text { Yang et } & \text { Time-series } & \mathrm{NO}_{2}, \mathrm{O}_{3}, & 1994-1998 & 6,027 & \text { Hospital } \\ \text { al.,2005 } & \text { study } & \mathrm{SO}_{2}, \mathrm{CO} & \text { Canada } & \text { M:F(N/A) } & \text { Admissions } \\ {[50]} & & & & \geq 65 \text { years } & \end{array}$

$\begin{array}{lcccc}\text { Stieb et } & \text { Time-series } & \mathrm{NO}_{2}, \mathrm{O}_{3}, & 1990-2000 & 40,491 \\ \text { al.,2009 } & \text { study } & \mathrm{SO}_{2}, \mathrm{CO}, & \text { Canada } & \mathrm{M}: \mathrm{F}(\mathrm{N} / \mathrm{A}) \\ {[81]} & & \mathrm{PM}_{2.5}, \mathrm{PM}_{10} & & (>18 \text { years })\end{array}$

severity and hospitalizations due to COPD exacerbations.

Outdoor air pollution was associed with adverse effects on symptoms in patients with COPD.

$\mathrm{NO}_{2}$ and $\mathrm{CO}$ were significantly associated with hospitalization for COPD, and the magnitude of effects was increased slightly with increasing days of exposure

Hospital In this large multicenter analysis, Admissions daily average concentrations of $\mathrm{CO}$ and $\mathrm{NO}_{2}$ exhibited the most consistent associations with ED visits for cardiac conditions, while $\mathrm{O}_{3}$ exhibited the most consistent associations with visits for respiratory conditions.

\footnotetext{
Abbreviations: AECOPD: acute exacerbation of chronic obstructive pulmonary disease; BC: black carbon; BS: black smoke; CI: confidence interval; CO: carbon monoxide; COPD: chronic obstructive pulmonary disease; ED: emergency department; MI: myocardial infarction; $\mathrm{NO}_{2}$ : nitrogen dioxide; $\mathrm{O}_{3}$ : ozone; OR: odds ratio; $\mathrm{PM}_{10}$ : particulate matter less than $10 \mu \mathrm{g} / \mathrm{m}^{3}$ in aerodynamic diameter; $\mathrm{PM}_{2.5:}$ particulate matter less than $2.5 \mu \mathrm{g} / \mathrm{m}^{3}$ in aerodynamic diameter; $\mathrm{SO}_{2}$ : sulfur dioxide; RR: relative risk; SPM: suspended particulate matter; TSP: total suspended particles; UFP: ultrafine particles.
}

\subsection{Influence of sex and age variables in the effects of short-term exposure to air pollution on AECOPD}

Of the forty studies identified in this review, twenty-one reported the sex of the study participants, including one study enrolling only female patients [48], and one including all male patients [79]. In addition, seven studies reported AECOPD results disaggregated by sex $[47,53,58,59,63,67,68]$, even though only four of these included the total number of male and female patients enrolled $[47,53,58,68]$. Overall, all studies found that there were significant associations between exposure to air pollutants and hospital admissions due to AECOPD.

A total of 426,630 hospital admissions for COPD were recorded in all 7 studies combined $[47,53,58,59,63,67,68]$. On average, there were approximately 409 admission counts per day, with males accounting for $72 \%$ (296 admissions) and females for 28\% (113 admissions). After adjusting for potential confounders, $\mathrm{SO}_{2}, \mathrm{NO}_{2}$, and $\mathrm{O}_{3}$ concentrations were significantly associated with increases in AECOPD hospitalizations in both sexes. Additionally, the relative risks (95\%CIs) of AECOPD hospitalization in association with an 
inter-quartile range increase in air pollutants for $10 \mathrm{mg} / \mathrm{m}^{3}$ increases in $\mathrm{PM}_{10}, \mathrm{SO}_{2}$ and $\mathrm{NO}_{2}$, respectively were analyzed in single model in two studies [58,67]. In these, it was found that the relative risks of exposure to these pollutants were lower for males than for females, except for PM10 exposure.

Table 2 summarizes the descriptive statistics on the average AECOPD daily hospitalizations and the daily levels of the six environmental risk factors from the only 7 studies identified that compared male and female patient outcomes $[47,53,58,59,63,67,68]$. Six of these studies were conducted in China, and one in Brazil. Overall, all studies identified more male than female patients with AECOPD (42.3 males vs. 16.1 females on average) in the total population analyzed, although all studies also enrolled more male patients than female patients (Table 2). In addition, while reporting results of AECOPD cases by sex, 3 of these studies failed to report the total number of male and female total patients enrolled $[59,63,67]$.

In the only 4 studies reporting the number of male and female patients enrolled [47, $53,58,68]$, the percentage of patients that developed AECOPD was similar for both sexes in all but one study, where the hospitalizations for female patients were twice as high as those for males $(0.39 \%$ vs. $0.18 \%$, respectively, Table 2$)$ [47]. Interestingly, this study reported some of the higher concentration averages for $\mathrm{PM}_{2.5}, \mathrm{PM}_{10}$, and $\mathrm{SO}_{2}(60,102$, and 52 $\mu \mathrm{g} / \mathrm{m}^{3}$, respectively), as well as maximum values, when compared to the rest of the studies that also reported sex-disaggregated data (Table 2).

Table 2. Summary of daily hospital admissions for AECOPD in men and women, and 24-hour average air pollutant concentrations

\begin{tabular}{|c|c|c|c|c|c|c|c|}
\hline & \multicolumn{7}{|c|}{ Studies } \\
\hline & $\begin{array}{c}\text { Du et } \\
\text { al.,2021 [68] } \\
\text { Jinhua, } \\
\text { China } \\
\text { (>65 years) }\end{array}$ & $\begin{array}{c}\text { Cai et } \\
\text { al.,2015 [63] } \\
\text { Shanghai, } \\
\text { China } \\
\text { (>18 years) }\end{array}$ & $\begin{array}{c}\text { Tao et } \\
\text { al.,2014 [58] } \\
\text { Lanzhou, } \\
\text { China } \\
\text { (>18 years) }\end{array}$ & $\begin{array}{c}\text { Tian et } \\
\text { al.,2014 [59] } \\
\text { Hong Kong, } \\
\text { China } \\
\text { (>18 years) }\end{array}$ & $\begin{array}{c}\text { Chen et } \\
\text { al.,2019 } \\
\text { [47] } \\
\text { Shenyang, } \\
\text { China } \\
\text { (>65 years) }\end{array}$ & $\begin{array}{c}\text { Liang et } \\
\text { al.,2019 } \\
\text { [67] } \\
\text { Beijing, } \\
\text { China } \\
\text { (>18 years) }\end{array}$ & $\begin{array}{c}\text { Arbex et } \\
\text { al.,2009 [53] } \\
\text { São Paulo, } \\
\text { Brazil } \\
\text { (>40 years) }\end{array}$ \\
\hline \multicolumn{8}{|c|}{ Gaseous pollutants concentration ( $24 \mathrm{~h}$ average), mean (min-max) } \\
\hline $\begin{array}{c}\mathrm{CO} \\
\left(\mu \mathrm{g} / \mathrm{m}^{3}\right)\end{array}$ & $\begin{array}{c}0.7 \\
(0.5-1.0)\end{array}$ & $\begin{array}{c}1.3 \\
(0.2-3.9)\end{array}$ & NR & $\begin{array}{c}0.6 \\
(0.1-2.1)\end{array}$ & NR & $\begin{array}{c}1.2 \\
(0.2-8.0)\end{array}$ & $\begin{array}{c}2.7 \\
(1.0-12.0)\end{array}$ \\
\hline $\mathrm{NO}_{2}\left(\mu \mathrm{g} / \mathrm{m}^{3}\right)$ & $\begin{array}{c}28.0 \\
(10.0-48.0)\end{array}$ & $\begin{array}{c}61.0 \\
(13.0-153.0)\end{array}$ & $\begin{array}{c}45.8 \\
(4.0-26.0)\end{array}$ & $\begin{array}{c}40.9 \\
(2.5-129.2)\end{array}$ & $\begin{array}{c}43.0 \\
(13.0-125.0)\end{array}$ & $\begin{array}{c}50.5 \\
(8.0-155.0)\end{array}$ & $\begin{array}{c}120.3 \\
(30.9-390.8)\end{array}$ \\
\hline $\begin{array}{c}\mathrm{SO}_{2} \\
\left(\mu \mathrm{g} / \mathrm{m}^{3}\right)\end{array}$ & $\begin{array}{c}7.2 \\
(3.0-13.0)\end{array}$ & $\begin{array}{c}53.0 \\
(8.0-223.0)\end{array}$ & $\begin{array}{c}79.1 \\
(2.0-37.1)\end{array}$ & NR & $\begin{array}{c}52.0 \\
(3.0-333.0)\end{array}$ & $\begin{array}{c}15.1 \\
(2.0-139.0)\end{array}$ & $\begin{array}{c}14.0 \\
(2.1-42.9)\end{array}$ \\
\hline $\begin{array}{c}\mathrm{O}_{3} \\
\left(\mu \mathrm{g} / \mathrm{m}^{3}\right)\end{array}$ & $\begin{array}{c}84.5 \\
(36.0-142.0)\end{array}$ & NR & NR & NR & $\begin{array}{c}58.0 \\
(9.0-218.0)\end{array}$ & $\begin{array}{c}95.8 \\
(2.0-292.0)\end{array}$ & $\begin{array}{c}95.8 \\
(14.5-282.0)\end{array}$ \\
\hline \multicolumn{8}{|c|}{ Particulate pollutants concentration ( $24 \mathrm{~h}$ average), mean (min-max) } \\
\hline $\mathrm{PM}_{2.5}\left(\mu \mathrm{g} / \mathrm{m}^{3}\right)$ & $\begin{array}{c}30.9 \\
(14.0-57.0)\end{array}$ & NR & NR & $\begin{array}{c}37.6 \\
(6.8-163.2)\end{array}$ & $\begin{array}{c}60.0 \\
(4.0-848.0)\end{array}$ & $\begin{array}{c}76.7 \\
(5.0-467.0)\end{array}$ & NR \\
\hline $\mathrm{PM}_{10}\left(\mu \mathrm{g} / \mathrm{m}^{3}\right)$ & $\begin{array}{c}50.1 \\
(25.0-84.0)\end{array}$ & $\begin{array}{c}92.0 \\
(12.0-643.0)\end{array}$ & $\begin{array}{c}196.63 \\
(16.0-256.1)\end{array}$ & NR & $\begin{array}{c}102.0 \\
(8.0-912.0)\end{array}$ & $\begin{array}{c}109.7 \\
(10.0-820.0)\end{array}$ & $\begin{array}{c}48.7 \\
(9.6-169.0)\end{array}$ \\
\hline
\end{tabular}




\begin{tabular}{|c|c|c|c|c|c|c|c|}
\hline \multicolumn{8}{|c|}{ Patients with AECOPD ( $24 \mathrm{~h}$ average), mean (min-max) } \\
\hline $\begin{array}{l}\text { Male (\% of total) } \\
\quad \text { (range) } \\
\% \text { of enrolled (n) }\end{array}$ & $\begin{array}{c}106(81.5 \%) \\
(73-144) \\
8.3 \%(1,277)\end{array}$ & $\begin{array}{c}72(64.9 \%) \\
(10-231) \\
\text { N/A }\end{array}$ & $\begin{array}{c}2(69 \%) \\
(0-13) \\
0.05 \% \\
(3,663)\end{array}$ & $\begin{array}{c}46(80.7 \%) \\
(13-91) \\
\text { N/A }\end{array}$ & $\begin{array}{c}9(52.9 \%) \\
(0-16) \\
0.18 \% \\
(4,920)\end{array}$ & $\begin{array}{c}60(67.4 \%) \\
(9-153) \\
\text { N/A }\end{array}$ & $\begin{array}{c}0.9(52.9 \%) \\
\quad(0-6) \\
0.09 \%(975)\end{array}$ \\
\hline $\begin{array}{c}\text { Female (\% of total) } \\
\text { (range) } \\
\% \text { of enrolled }(\mathrm{n})\end{array}$ & $\begin{array}{c}24(18.4 \%) \\
\quad(32-16) \\
8.4 \%(286)\end{array}$ & $\begin{array}{c}39(35.1 \%) \\
(3-137) \\
\text { N/A }\end{array}$ & $\begin{array}{c}0.9(31 \%) \\
(0-6) \\
0.05 \% \\
(1,638)\end{array}$ & $\begin{array}{c}11(19.3 \%) \\
(0-34) \\
\text { N/A }\end{array}$ & $\begin{array}{c}8(47.1 \%) \\
(0-15) \\
0.39 \% \\
(2,061)\end{array}$ & $\begin{array}{c}29(32.6 \%) \\
(2-90) \\
\text { N/A }\end{array}$ & $\begin{array}{c}0.8(47.1 \%) \\
\quad(0-7) \\
0.10 \%(794)\end{array}$ \\
\hline $\begin{array}{c}\text { Total } \\
\text { (range) } \\
\% \text { of enrolled } \\
\text { (n) }\end{array}$ & $\begin{array}{c}130 \\
(89-176) \\
8.3 \% \\
(1563)\end{array}$ & $\begin{array}{c}111 \\
(14-368) \\
0.09 \% \\
(121,463)\end{array}$ & $\begin{array}{c}2.9 \\
(0-13) \\
0.06 \% \\
(5,301)\end{array}$ & $\begin{array}{c}57 \\
(17-117) \\
0.05 \% \\
(117,329)\end{array}$ & $\begin{array}{c}17 \\
(0-31) \\
0.39 \% \\
(4,409)\end{array}$ & $\begin{array}{c}89 \\
(17-220) \\
0.05 \% \\
(161,613)\end{array}$ & $\begin{array}{c}1.7 \\
(0-10) \\
0.10 \% \\
(1,769)\end{array}$ \\
\hline
\end{tabular}

Abbreviations: AECOPD: acute exacerbation chronic obstructive pulmonary disease; PM10- particulate matter of less than 10 microns in aerodynamic diameter; $\mathrm{PM}_{2.5-}$ particulate matter less than 2.5 microns in aerodynamic diameter; Min: minimum; Max: maximum; NR: not reported; N/A: data not available.

Regarding age, most studies enrolled patients over 18 years of age, except one study that enrolled patients over 40 [53] and two studies enrolling patients over 65 [47,68]. Combined, these studies revealed that the relative risk for AECOPD for patients aged $\leq 65$ years is lower than that of patients aged $\geq 65$ years (Table 2). In addition, Tao et al. reported that the relative risk for COPD exacerbations was higher in elder females than males with increases in $\mathrm{PM}_{10}, \mathrm{NO}_{2}$, and $\mathrm{SO}_{2}$ concentrations at lag 1-4 [58]. This concurs with results from previous studies suggesting that females and the elderly are some of the most vulnerable groups to outdoor air pollution [3,82-85].

\subsection{Weather and geographic influences in air pollution effects on $A E C O P D$}

Studies conducted in different countries independently identified significant associations of temperature, humidity, and various air pollutants with hospital admissions in COPD patients. In a study conducted in Spain, de Miguel-Díez et al. found that COPD was negatively affected by colder climatological factors and exposure to $\mathrm{O}_{3}, \mathrm{CO}, \mathrm{PM}_{10}$ and $\mathrm{NO}_{2}$ [77]. In a multipollutant model in Hong Kong, $\mathrm{SO}_{2}, \mathrm{NO}_{2}, \mathrm{PM}_{10}$, and $\mathrm{O}_{3}$ were also shown to display a greater effect on AECOPD admissions in the cold season (December to March) than in the warm season [52]. On the other hand, a study in Taiwan showed that during the warmer season, COPD exacerbations occurred more frequently on days of temperature increases than on other days [86]. Stieb et al. also found that associations tended to be of greater magnitude during the warm season (April - September) in seven Canadian cities during the 1990s and early 2000s [81]. Another study in Romania reported that the adverse effect of PM exposure on chronic bronchitis was reduced by higher humidity, and that dry air aggravated the adverse effects of PM exposure in COPD patients [49]. Finally, $\mathrm{Du}$ et al. found that $\mathrm{O}_{3}$ was the most closely spatially correlated with AECOPD hospitalizations at sites located in the northwest region of Jinhua, China, likely due to many industrial complexes in this region [68].

\subsection{Symptoms in the respiratory response to shorter-term exposure to air pollution}

Regarding COPD exacerbation symptoms, most studies showed that COPD symptoms, but not lung function, were mainly associated with raises in air pollution levels. Of these, dyspnea was significantly associated with PM10 with an increase in odds for an interquartile range change in pollutant of $13 \%$ (95\% CI $4 \%$ to $23 \%$ ) which is one common approach to presenting multi-pollutant health effect estimates, and this association 
remained significant after adjustment for other pollutant exposures [79]. In addition, short-term exposure to traffic pollution was shown to prevent the beneficial cardiopulmonary effects of walking in individuals with COPD [70].

\section{Discussion}

Chronic Obstructive Pulmonary Disease (COPD) is an inflammatory lung disease involving chronic bronchitis and emphysema. Patients with COPD are particularly vulnerable to the detrimental effects of environmental exposures, especially from air particulate and gaseous pollutants. While sex and gender differences in COPD prevalence and severity have been previously reported, sex-specific effects of air pollution exposure on COPD exacerbations and hospitalizations have not been studied in detail. The available evidence indicates that outdoor air pollution exposure affects lung function and triggers exacerbations in both male and female COPD patients. However, in reviewing the literature, we found that most studies conducted in this area have not accounted for sex in their analyses.

Our review of the literature identified 40 studies measuring associations of air pollution exposures and AECOPD. In these, it was widely reported that increases in environmental particulate and gaseous pollution concentrations were associated with increased risk of hospitalization for AECOPD, with varying effects depending on air quality composition, pollutant concentration, and time of exposure. We found that the majority of these studies enrolled mostly male subjects, and some enrolled men exclusively. This was a surprising finding considering that the incidence of COPD among women has increased in the past few decades [3]. Potential factors that may contribute to this bias are the historical (although not current) higher incidence of tobacco use in men, occupational exposures, and the previously described gender bias in COPD diagnosis [10,11,87-89].

This study has several limitations. First, the number of studies identified by the selection criteria was limited and overrepresented in European and Asian countries, and the studies including or reporting participant data disaggregated by sex was markedly low, severely limiting the implications of our findings and our ability to conduct an analysis beyond descriptive. Second, our literature search was based on only two databases and including only studies in English, which could have omitted work available in other databases or languages, leading to selection bias. Third, using hospitalization rates as a comparison measure could also lead to bias, since hospitalization criteria may vary among countries and health systems, and since mortality associated with hospitalization for AECOPD does not always occur in the hospital.

This study has also several strenghts. First, it is the first review of the literature available assessing sex differences in an important outcome of the COPD pathogenesis and its relationship with air quality (i.e., hospitalization and mortality). Second, this study revealed a major gap in the research conducted to date in the area of COPD associations with air pollution in men and women, highlighting the importance of research design strategies that will identify sex- and gender- specific factors. Third, our review of the literature identified multiple studies where associations of air quality measures and AECOPD hospitalizations were reported, highlighting the importance of more research in these areas in order to design better preventative measures for COPD patients who live in geographical locations with poor air quality.

In the past few decades, the number of studies assessing the effects of air pollution exposure on lung disease has considerably increased [90]. However, studies considering sex (a biologic factor), or gender (a social construct, often used to refer to sex in publications) have been limited. Likewise, sex-specific disaggregation of data in the Global Burden of Diseases study has revealed that there are substantial differences between men and women that are frequently overlooked due to limitations in study designs [91]. This is highlighted by our findings in which only seven studies reported sex-disaggregated results, and only four studies had sufficient information to compare outcomes between male and female patients. Therefore, future studies should consider incorporating sex and 
gender variables at the design stage, and perform sex and gender disaggregated results reporting and analysis.

\section{Conclusions}

In conclusion, the available literature indicates that air pollution exposure is a relevant risk factor for AECOPD hospitalizations, although there is a significant absence of studies assessing sex-specific effects in this area. This review emphasizes the need of more studies designed to address sex- and gender-specific effects of air pollution exposure, as well as studies including women, a vulnerable population.

Author Contributions: Conceptualization, M.E.S.R. and P.S.; methodology, M.E.S.R. and P.S.; formal analysis, M.E.S.R. and P.S.; investigation, M.E.S.R. and P.S.; resources, M.E.S.R. and P.S.; data curation, M.E.S.R. and P.S.; writing - original draft preparation, M.E.S.R.; writing - review and editing, M.E.S.R. and P.S.; visualization, M.E.S.R. and P.S.; supervision, P.S.; project administration, P.S.; funding acquisition, P.S. All authors have read and agreed to the published version of the manuscript.

Funding: This research received no external funding. The APC was funded by Indiana University Bloomington.

Conflicts of Interest: The authors declare no conflicts of interest.

\section{References}

1. Celli, B.R.; Decramer, M.; Wedzicha, J.A.; Wilson, K.C.; Agustí, A.; Criner, G.J.; MacNee, W.; Make, B.J.; Rennard, S.I.; Stockley, R.A., et al. An Official American Thoracic Society/European Respiratory Society Statement: Research questions in chronic obstructive pulmonary disease. Am J Respir Crit Care Med 2015, 191, e4-e27

2. Akinbami, L.J.; Liu, X. Chronic obstructive pulmonary disease among adults aged 18 and over in the United States, 1998-2009. NCHS Data Brief 2011, 1-8.

3. Varkey, A.B. Chronic obstructive pulmonary disease in women: exploring gender differences. Curr Opin Pulm Med 2004, 10, 98103

4. Han, M.K.; Arteaga-Solis, E.; Blenis, J.; Bourjeily, G.; Clegg, D.J.; DeMeo, D.; Duffy, J.; Gaston, B.; Heller, N.M.; Hemnes, A., et al. Female Sex and Gender in Lung/Sleep Health and Disease. Increased Understanding of Basic Biological, Pathophysiological, and Behavioral Mechanisms Leading to Better Health for Female Patients with Lung Disease. Am J Respir Crit Care Med 2018, 198, 850-858

5. Sørheim, I.C.; Johannessen, A.; Gulsvik, A.; Bakke, P.S.; Silverman, E.K.; DeMeo, D.L. Gender differences in COPD: are women more susceptible to smoking effects than men? Thorax 2010, 65, 480-485

6. American Lung Association. COPD Prevalence. Availabe online: https://www.lung.org/research/trends-in-lung-disease/copdtrends-brief/copd-prevalence

7. Soriano, J.B. An Epidemiological Overview of Chronic Obstructive Pulmonary Disease: What Can Real-Life Data Tell Us about Disease Management? COPD 2017, 14, S3-S7

8. Pauwels, R.A.; Buist, A.S.; Calverley, P.M.; Jenkins, C.R.; Hurd, S.S.; Committee, G.S. Global strategy for the diagnosis, management, and prevention of chronic obstructive pulmonary disease. NHLBI/WHO Global Initiative for Chronic Obstructive Lung Disease (GOLD) Workshop summary. Am J Respir Crit Care Med 2001, 163, 1256-1276.

9. Hansel, N.N.; McCormack, M.C.; Kim, V. The Effects of Air Pollution and Temperature on COPD. COPD 2016, 13, 372-379

10. Aryal, S.; Diaz-Guzman, E.; Mannino, D.M. Influence of sex on chronic obstructive pulmonary disease risk and treatment outcomes. Int J Chron Obstruct Pulmon Dis 2014, 9, 1145-1154

11. Aryal, S.; Diaz-Guzman, E.; Mannino, D.M. COPD and gender differences: an update. Transl Res 2013, 162, 208-218

12. Mannino, D.M.; Buist, A.S. Global burden of COPD: risk factors, prevalence, and future trends. Lancet 2007, 370, 765-773

13. de Torres, J.P.; Cote, C.G.; Lopez, M.V.; Casanova, C.; Diaz, O.; Marin, J.M.; Pinto-Plata, V.; de Oca, M.M.; Nekach, H.; Dordelly, L.J., et al. Sex differences in mortality in patients with COPD. Eur Respir J 2009, 33, 528-535

14. Balmes, J.R. When smoke gets in your lungs. Proc Am Thorac Soc 2010, 7, 98-101

15. Global Burden of Disease Collaborators. Prevalence and attributable health burden of chronic respiratory diseases, 1990-2017: a systematic analysis for the Global Burden of Disease Study 2017. Lancet Respir Med 2020, 8, 585-596

16. Orru, H.; Ebi, K.L.; Forsberg, B. The Interplay of Climate Change and Air Pollution on Health. Curr Environ Health Rep 2017, 4 , 504-513

17. Ogawa, K.; Kishi, K. [Etiological and exacerbation factors for COPD. Air pollution]. Nihon Rinsho 2016, 74, 743-746

18. Perez, T.A.; Castillo, E.G.; Ancochea, J.; Pastor Sanz, M.T.; Almagro, P.; Martínez-Camblor, P.; Miravitlles, M.; Rodríguez-Carballeira, M.; Navarro, A.; Lamprecht, B., et al. Sex differences between women and men with COPD: A new analysis of the 3CIA study. Respir Med 2020, 171, 106105 
19. Sood, A.; Assad, N.A.; Barnes, P.J.; Churg, A.; Gordon, S.B.; Harrod, K.S.; Irshad, H.; Kurmi, O.P.; Martin, W.J.; Meek, P., et al. ERS/ATS workshop report on respiratory health effects of household air pollution. Eur Respir J 2018, 51,1700698

20. Rider, C.F.; Carlsten, C. Air pollution and DNA methylation: effects of exposure in humans. Clinical epigenetics 2019, 11, 131

21. Baccarelli, A.; Wright, R.O.; Bollati, V.; Tarantini, L.; Litonjua, A.A.; Suh, H.H.; Zanobetti, A.; Sparrow, D.; Vokonas, P.S.; Schwartz, J. Rapid DNA methylation changes after exposure to traffic particles. Am J Respir Crit Care Med 2009, 179, 572-578

22. van Voorhis, M.; Knopp, S.; Julliard, W.; Fechner, J.H.; Zhang, X.; Schauer, J.J.; Mezrich, J.D. Exposure to atmospheric particulate matter enhances Th17 polarization through the aryl hydrocarbon receptor. PLoS One 2013, 8, e82545

23. Rebuli, M.E.; Speen, A.M.; Martin, E.M.; Addo, K.A.; Pawlak, E.A.; Glista-Baker, E.; Robinette, C.; Zhou, H.; Noah, T.L.; Jaspers, I. Wood Smoke Exposure Alters Human Inflammatory Responses to Viral Infection in a Sex-Specific Manner: A Randomized, Placebo-Controlled Study. Am J Respir Crit Care Med 2018, 996-1007

24. Glencross, D.A.; Ho, T.R.; Camiña, N.; Hawrylowicz, C.M.; Pfeffer, P.E. Air pollution and its effects on the immune system. Free radical biology \& medicine 2020, 151, 56-68

25. Guo, C.; Sun, X.; Diao, W.; Shen, N.; He, B. Correlation of Clinical Symptoms and Sputum Inflammatory Markers with Air Pollutants in Stable COPD Patients in Beijing Area. International journal of chronic obstructive pulmonary disease 2020, 15,

26. Ling, S.; van Eeden, S.F.. Particulate matter air pollution exposure: role in the development and exacerbation of chronic obstructive pulmonary disease. International journal of chronic obstructive pulmonary disease 2009, 4, 233-243

27. Pope, D.; Diaz, E.; Smith-Sivertsen, T.; Lie, R.T.; Bakke, P.; Balmes, J.R.; Smith, K.R.; Bruce, N.G. Exposure to household air pollution from wood combustion and association with respiratory symptoms and lung function in nonsmoking women: results from the RESPIRE trial, Guatemala. Environ Health Perspect 2015, 123, 285-292

28. Salvi, S.S.; Barnes, P.J. Chronic obstructive pulmonary disease in non-smokers. Lancet 2009, 374, 733-743

29. Salvi, S.; Barnes, P.J. Is exposure to biomass smoke the biggest risk factor for COPD globally? Chest 2010, 138, 3-6

30. Doneva, M.; Petrova, G.; Petrova, D.; Kamusheva, M.; Petkova, V.; Tachkov, K.; Pencheva, V.; Georgiev, O. Chronic obstructive pulmonary disease exacerbations and progression in relation to ambient air pollutants exposure. J Thorac Dis 2019, 11, 24902497

31. Wedzicha, J.A.; Seemungal, T.A.R. COPD exacerbations: defining their cause and prevention. Lancet (London, England) 2007, 370, 786-96

32. Mackay, A.; Hurst, J.R. COPD exacerbations: causes, prevention, and treatment. The Medical clinics of North America 2012, 96, 789-809

33. Morantes-Caballero, J.A.; Fajardo Rodriguez, H.A. Effects of air pollution on acute exacerbation of chronic obstructive pulmonary disease: a descriptive retrospective study (pol-AECOPD). Int J Chron Obstruct Pulmon Dis 2019, 14, 1549-1557

34. Pooler, A.; Beech, R. Examining the relationship between anxiety and depression and exacerbations of COPD which result in hospital admission: a systematic review. International journal of chronic obstructive pulmonary disease 2014, 9, 315-30

35. Kunadharaju, R.; Sethi, S. Treatment of Acute Exacerbations in Chronic Obstructive Pulmonary Disease. Clinics in chest medicine 2020, 41, 439-451

36. Gao, N.; Xu, W.; Ji, J.; Yang, Y.; Wang, S.T.; Wang, J.; Chen, X.; Meng, S.; Tian, X.; Xu, K.F. Lung function and systemic inflammation associated with short-term air pollution exposure in chronic obstructive pulmonary disease patients in Beijing, China. Environ Health 2020, 19, 12

37. Hansel, N.N.; McCormack, M.C.; Kim, V. H. The Effects of Air Pollution and Temperature on COPD. COPD 2016, 13, 372-9

38. Yan, P.; Liu, P.; Lin, R.; Xiao, K.; Xie, S.; Wang, K.; Zhang, Y.; He, X.; Zhao, S.; Zhang, X. et al. Effect of ambient air quality on exacerbation of COPD in patients and its potential mechanism. International journal of chronic obstructive pulmonary disease 2019, $14,1517-1526$

39. Duan, R.R.; Hao, K.; Yang, T. Air pollution and chronic obstructive pulmonary disease. Chronic Dis Transl Med 2020, 6, 260-269

40. Pini, L.; Giordani, J.; Gardini, G.; Concoreggi, C.; Pini, A.; Perger, E.; Vizzardi, E.; Di Bona, D.; Cappelli, C.; Ciarfaglia, M., et al. Emergency department admission and hospitalization for COPD exacerbation and particulate matter short-term exposure in Brescia, a highly polluted town in northern Italy. Respir Med 2021, 179, 106334

41. DeVries, R.; Kriebel, D.; Sama, S. Low level air pollution and exacerbation of existing copd: a case crossover analysis. Environ Health 2016, 15, 98

42. Owaga, K.; Kishi, K. [Etiological and exacerbation factors for COPD. Air pollution]. Nihon rinsho. Japanese journal of clinical medicine 2016, 74, 743-6

43. Grabicki, M.; Kuźnar-Kamińska, B.; Rubinsztajn, R.; Brajer-Luftmann, B.; Kosacka, M.; Nowicka, A.; Piorunek, T.; Kostrzewska, M.; Chazan, R.; Batura-Gabryel, H. COPD Course and Comorbidities: Are There Gender Differences? Adv Exp Med Biol 2019, $1113,43-51$

44. Raherison, C.; Tillie-Leblond, I.; Prudhomme, A.; Taillé, C.; Biron, E.; Nocent-Ejnaini, C.; Mathieu, B.; Ostinelli, J. Clinical characteristics and quality of life in women with COPD: an observational study. BMC Womens Health 2014, 14, 31

45. Han, M.K.; Postma, D.; Mannino, D.M.; Giardino, N.D.; Buist, S.; Curtis, J.L.; Martinez, F.J. Gender and chronic obstructive pulmonary disease: why it matters. Am J Respir Crit Care Med 2007, 176, 1179-1184

46. Kloog, I.; Nordio, F.; Zanobetti, A.; Coull, B.A.; Koutrakis, P.; Schwartz, J.D. Short term effects of particle exposure on hospital admissions in the Mid-Atlantic states: a population estimate. PLoS One 2014, 9, e88578

47. Chen, C.; Wang, X.; Lv, C.; Li, W.; Ma, D.; Zhang, Q.; Dong, L. The effect of air pollution on hospitalization of individuals with respiratory and cardiovascular diseases in Jinan, China. Medicine (Baltimore) 2019, 98, e15634 
48. Hendryx, M.; Luo, J.; Chojenta, C.; Byles, J.E. Air pollution exposures from multiple point sources and risk of incident chronic obstructive pulmonary disease (COPD) and asthma. Environ Res 2019, 179, 108783

49. Leitte, A.M.; Petrescu, C.; Franck, U.; Richter, M.; Suciu, O.; Ionovici, R.; Herbarth, O.; Schlink, U. Respiratory health, effects of ambient air pollution and its modification by air humidity in Drobeta-Turnu Severin, Romania. Sci Total Environ 2009, 407, 40044011

50. Yang, Q.; Chen, Y.; Krewski, D.; Burnett, R.T.; Shi, Y.; McGrail, K.M. Effect of short-term exposure to low levels of gaseous pollutants on chronic obstructive pulmonary disease hospitalizations. Environ Res 2005, 99, 99-105

51. Cho, J.; Choi, Y.J.; Suh, M.; Sohn, J.; Kim, H.; Cho, S.K.; Ha, K.H.; Kim, C.; Shin, D.C. Air pollution as a risk factor for depressive episode in patients with cardiovascular disease, diabetes mellitus, or asthma. J Affect Disord 2014, 157, 45-51

52. Ko, F.W.; Tam, W.; Wong, T.W.; Chan, D.P.; Tung, A.H.; Lai, C.K.; Hui, D.S. Temporal relationship between air pollutants and hospital admissions for chronic obstructive pulmonary disease in Hong Kong. Thorax 2007, 62, 780-785

53. Arbex, M.A.; de Souza Conceição, G.M.; Cendon, S.P.; Arbex, F.F.; Lopes, A.C.; Moysés, E.P.; Santiago, S.L.; Saldiva, P.H.; Pereira, L.A.; Braga, A.L. Urban air pollution and chronic obstructive pulmonary disease-related emergency department visits. $J$ Epidemiol Community Health 2009, 63, 777-783

54. Wang, Z.; Zhou, Y.; Zhang, Y.; Huang, X.; Duan, X.; Chen, D.; Ou, Y.; Tang, L.; Liu, S.; Hu, W., et al. Association of change in air quality with hospital admission for acute exacerbation of chronic obstructive pulmonary disease in Guangdong, China: A province-wide ecological study. Ecotoxicol Environ Saf 2021, 208, 111590

55. Milutinović, S.; Nikić, D.; Stosić, L.; Stanković, A.; Bogdanović, D. Short-term association between air pollution and emergency room admissions for chronic obstructive pulmonary disease in Nis, Serbia. Cent Eur J Public Health 2009, 17, 8-13

56. Zhang, Z.; Wang, J.; Chen, L.; Chen, X.; Sun, G.; Zhong, N.; Kan, H.; Lu, W. Impact of haze and air pollution-related hazards on hospital admissions in Guangzhou, China. Environ Sci Pollut Res Int 2014, 21, 4236-4244

57. Qiu, H.; Yu, I.T.; Tian, L.; Wang, X.; Tse, L.A.; Tam, W.; Wong, T.W. Effects of coarse particulate matter on emergency hospital admissions for respiratory diseases: a time-series analysis in Hong Kong. Environ Health Perspect 2012, 120, 572-576

58. Tao, Y.; Mi, S.; Zhou, S.; Wang, S.; Xie, X. Air pollution and hospital admissions for respiratory diseases in Lanzhou, China. Environ Pollut 2014, 185, 196-201

59. Tian, L.; Ho, K.F.; Wang, T.; Qiu, H.; Pun, V.C.; Chan, C.S.; Louie, P.K.; Yu, I.T. Ambient carbon monoxide and the risk of hospitalization due to chronic obstructive pulmonary disease. Am J Epidemiol 2014, 180, 1159-1167

60. Chen, Y.; Yang, Q.; Krewski, D.; Shi, Y.; Burnett, R.T.; McGrail, K. Influence of relatively low level of particulate ar pollution on hospitalization for COPD in elderly people. Inhal Toxicol 2004, 16, 21-25

61. To, T.; Feldman, L.; Simatovic, J.; Gershon, A.S.; Dell, S.; Su, J.; Foty, R.; Licskai, C. Health risk of air pollution on people living with major chronic diseases: a Canadian population-based study. BMJ Open 2015, 5, e009075

62. Sauerzapf, V.; Jones, A.P.; Cross, J. Environmental factors and hospitalisation for chronic obstructive pulmonary disease in a rural county of England. J Epidemiol Community Health 2009, 63, 324-328

63. Cai, J.; Chen, R.; Wang, W.; Xu, X.; Ha, S.; Kan, H. Does ambient CO have protective effect for COPD patient? Environ Res 2015, $136,21-26$

64. Yorifuji, T.; Suzuki, E.; Kashima, S. Hourly differences in air pollution and risk of respiratory disease in the elderly: a timestratified case-crossover study. Environ Health 2014, 13, 67

65. Schikowski, T.; Adam, M.; Marcon, A.; Cai, Y.; Vierkötter, A.; Carsin, A.E.; Jacquemin, B.; Al Kanani, Z.; Beelen, R.; Birk, M., et al. Association of ambient air pollution with the prevalence and incidence of COPD. Eur Respir J 2014, 44, 614-626

66. Yan, P.; Liu, P.; Lin, R.; Xiao, K.; Xie, S.; Wang, K.; Zhang, Y.; He, X.; Zhao, S.; Zhang, X., et al. Effect of ambient air quality on exacerbation of COPD in patients and its potential mechanism. Int J Chron Obstruct Pulmon Dis 2019, 14, 1517-1526

67. Liang, L.; Cai, Y.; Barratt, B.; Lyu, B.; Chan, Q.; Hansell, A.L.; Xie, W.; Zhang, D.; Kelly, F.J.; Tong, Z. Associations between daily air quality and hospitalisations for acute exacerbation of chronic obstructive pulmonary disease in Beijing, 2013-17: an ecological analysis. Lancet Planet Health 2019, 3, e270-e279

68. Du, W.; Zhang, W.; Hu, H.; Zhang, M.; He, Y.; Li, Z. Associations between ambient air pollution and hospitalizations for acute exacerbation of chronic obstructive pulmonary disease in Jinhua, 2019. Chemosphere 2021, 267, 128905

69. Lin, M.T..; Kor, C.T.; Chang, C.C.; Chai, W.H.; Soon, M.S.; Ciou, Y.S.; Lian, L.B.; Chang, C.C.. Association of meteorological factors and air NO 2 and $\mathrm{O} 3$ concentrations with acute exacerbation of elderly chronic obstructive pulmonary disease. Scientific reports 2018, 8, 10192

70. Sinharay, R.; Gong, J.; Barratt, B.; Ohman-Strickland, P.; Ernst, S.; Kelly, F.J.; Zhang, J.J.; Collins, P.; Cullinan, P.; Chung, K.F. Respiratory and cardiovascular responses to walking down a traffic-polluted road compared with walking in a traffic-free area in participants aged 60 years and older with chronic lung or heart disease and age-matched healthy controls: a randomised, crossover study. Lancet 2018, 391, 339-349

71. Chen, C.; Liu, X.; Wang, X.; Qu, W.; Li, W.; Dong, L. Effect of air pollution on hospitalization for acute exacerbation of chronic obstructive pulmonary disease, stroke, and myocardial infarction. Environ Sci Pollut Res Int 2020, 27, 3384-3400

72. Zieliński, M.; Gąsior, M.; Jastrzębski, D.; Desperak, A.; Ziora, D. Influence of particulate matter air pollution on exacerbation of chronic obstructive pulmonary disease depending on aerodynamic diameter and the time of exposure in the selected population with coexistent cardiovascular diseases. Adv Respir Med 2018, 86, 227-233

73. Gutierrez, M.P.; Zuidema, P.; Mirsaeidi, M.; Campos, M.; Kumar, N. Association between African Dust Transport and Acute Exacerbations of COPD in Miami. J Clin Med 2020, 9, 2496 
74. Chen, C.; Liu, X.; Wang, X.; Li, W.; Qu, W.; Dong, L.; Li, X.; Rui, Z.; Yang, X. Risk of temperature, humidity and concentrations of air pollutants on the hospitalization of AECOPD. PLoS One 2019, 14, e0225307

75. Kwon, S.O.; Hong, S.H.; Han, Y.J.; Bak, S.H.; Kim, J.; Lee, M.K.; London, S.J.; Kim, W.J.; Kim, S.Y. Long-term exposure to PM. Respir Res 2020, 21, 247

76. Reid, C.E.; Considine, E.M.; Watson, G.L.; Telesca, D.; Pfister, G.G.; Jerrett, M. Associations between respiratory health and ozone and fine particulate matter during a wildfire event. Environ Int 2019, 129, 291-298

77. de Miguel-Díez, J.; Hernández-Vázquez, J.; López-de-Andrés, A.; Álvaro-Meca, A.; Hernández-Barrera, V.; Jiménez-García, R. Analysis of environmental risk factors for chronic obstructive pulmonary disease exacerbation: A case-crossover study (20042013). PLoS One 2019, 14, e0217143

78. Stevanović, I.; Jovasević-Stojanović, M.; Stosić, J.J. Association between ambient air pollution, meteorological conditions and exacerbations of asthma and chronic obstructive pulmonary disease in adult citizens of the town of Smederevo. Vojnosanit Pregl 2016, 73, 152-158

79. Peacock, J.L.; Anderson, H.R.; Bremner, S.A.; Marston, L.; Seemungal, T.A.; Strachan, D.P.; Wedzicha, J.A. Outdoor air pollution and respiratory health in patients with COPD. Thorax 2011, 66, 591-596

80. Medina-Ramón, M.; Zanobetti, A.; Schwartz, J. The effect of ozone and PM10 on hospital admissions for pneumonia and chronic obstructive pulmonary disease: a national multicity study. Am J Epidemiol 2006, 163, 579-588

81. Stieb, D.M.; Szyszkowicz, M.; Rowe, B.H.; Leech, J.A. Air pollution and emergency department visits for cardiac and respiratory conditions: a multi-city time-series analysis. Environ Health 2009, 8, 25

82. Abramson, M.J.; Wigmann, C.; Altug, H.; Schikowski, T. Ambient air pollution is associated with airway inflammation in older women: a nested cross-sectional analysis. BMJ Open Respir Res 2020, 7, e000549

83. Bell, M.L.; Son, J.Y.; Peng, R.D.; Wang, Y.; Dominici, F. Ambient PM2.5 and Risk of Hospital Admissions: Do Risks Differ for Men and Women? Epidemiology 2015, 26, 575-579

84. Makri, A.; Stilianakis, N.I. Vulnerability to air pollution health effects. Int J Hyg Environ Health 2008, 211, 326-336

85. Butter, M.E. Are Women More Vulnerable to Environmental Pollution? Kamla-Raj: Journal of Human Ecology, 2006; Vol. 20, pp 221-336.

86. Lin, M.T.; Kor, C.T.; Chang, C.C.; Chai, W.H.; Soon, M.S.; Ciou, Y.S.; Bin Lian, I. Association of meteorological factors and air NO. Sci Rep 2018, 8, 10192

87. Chapman, K.R.; Tashkin, D.P.; Pye, D.J. Gender bias in the diagnosis of COPD. Chest 2001, 119, 1691-1695

88. Jenkins, C.R.; Chapman, K.R.; Donohue, J.F.; Roche, N.; Tsiligianni, I.; Han, M.K. Improving the Management of COPD in Women. Chest 2017, 151, 686-696

89. Lamprecht, B.; Soriano, J.B.; Studnicka, M.; Kaiser, B.; Vanfleteren, L.E.; Gnatiuc, L.; Burney, P.; Miravitlles, M.; García-Rio, F.; Akbari, K., et al. Determinants of underdiagnosis of COPD in national and international surveys. Chest 2015, 148, 971-985

90. Silveyra, P.; Fuentes, N.; Rodriguez Bauza, D.E. Sex and Gender Differences in Lung Disease. Adv Exp Med Biol 2021, 1304, 227258

91. The Lancet. GBD 2017: a fragile world. Lancet 2018, 392, 1683 